\title{
Ankyrin Repeat Domain-Containing Protein 26
}

National Cancer Institute

\section{Source}

National Cancer Institute. Ankyrin Repeat Domain-Containing Protein 26. NCI Thesaurus.

Code C151928.

Ankyrin repeat domain-containing protein 26 (1709 aa, 196 kDa) is encoded by the human ANKRD26 gene. This protein plays a role in appetite, platelet functions and adipogenesis. 